\title{
The ANK nail treatment of lateral malleolar fractures with syndesmosis injury: Clinical outcomes at 10 years of follow-up
}

\author{
(1) Sinan Kahraman, M.D., ${ }^{1}$ @ Hasan Hüseyin Ceylan, M.D., ${ }^{2}$ \\ 다 Mehmet Mesut Sönmez, M.D., ${ }^{3}$ ๑ Ayhan Nedim Kara, M.D. ${ }^{1}$
}

\begin{abstract}
1Department of Orthopaedics and Traumatology, İstanbul Bilim University Şişli Florence Nightingale Hospital, İstanbul-Turkey 2Department of Orthopaedics and Traumatology, İstanbul Lütfiye Nuri Burat State Hospital, İstanbul-Turkey

${ }^{3}$ Department of Orthopaedics and Traumatology, Hamidiye Şişli Etfal Training and Research Hospital, İstanbul-Turkey
\end{abstract}

\begin{abstract}
BACKGROUND: Lateral malleolar fractures associated with syndesmotic injuries are common. Various surgical implants may be used for the management of syndesmosis injury. One of these is ANK nail. The aim of the present study was to assess the clinical and radiological outcomes of patients treated with ANK nail.
\end{abstract}

METHODS: Forty-eight patients who were followed up for a minimum of 10 years were reviewed retrospectively using American Orthopedic Foot and Ankle Society (AOFAS) score, radiological evaluation, and development of posttraumatic arthritis. Final data were collected at the last follow-up.

RESULTS: The mean age of the patients was 37.3 (17-69) years. The mean follow-up was 129.9 (123-150) months. Twenty-two patients had Weber type B fracture, and their mean AOFAS score was 93.36 points. The remaining 26 patients had Weber type $C$ fracture, and their mean AOFAS score was $\mathbf{9 7 . 6 6}$ points. There was no relationship between the type of fracture and the clinical outcome. There was a significant correlation between shortening of the fibula and posttraumatic arthritis.

CONCLUSION: The ANK nail used for the management of ankle fractures may provide both fracture and syndesmosis stabilities in selected cases and is also a cost effective method as cheap as a cortical screw and a Kirschner wire.

Keywords: ANK nail; ankle fracture; syndesmosis injury.

\section{INTRODUCTION}

The distal tibiofibular syndesmosis is essential for the stability of the ankle mortise. The function of the syndesmosis ligament group is to maintain a balanced relationship between the tibia, fibula, and talus during ankle movements. Syndesmosis injury and widening of the ankle joint mortise may result in poor function and osteoarthritis. The incidence of ankle fractures has increased significantly due to an increase in sports activities. Its prevalence is approximately I-2 per 1000 people. ${ }^{[1-7]}$ Weber type B fractures ${ }^{[8]}$ and LaugeHansen ${ }^{[9]}$ supination external rotation injuries are the most common of all indirect fractures, and distal tibiofibular diastasis, also known as syndesmosis injury, is reported to occur in approximately $30 \%$ of these fractures. This is the most common clinical condition when evaluation and treatment of syndesmosis injury must be considered. The static fixation with one or multiple screws through three or four cortices is the conventional treatment in syndesmosis repair. ${ }^{[10,11]}$ The syndesmosis screw should be removed after the procedure, otherwise local symptoms and complications may occur due to fixation. Removal of the screw is another surgical procedure exposing the patient to the disadvantage for a second surgical intervention. ${ }^{[1,12]}$

Cite this article as: Kahraman S, Ceylan HH, Sönmez MM, Kara AN. The ANK nail treatment of lateral malleolar fractures with syndesmosis injury: Clinical outcomes at 10 years of follow-up. Ulus Travma Acil Cerrahi Derg 2019;25:75-79.

Address for correspondence: Sinan Kahraman, M.D.

Hamidiye Şişli Etfal Ĕgitim ve Araştırma Hastanesi, Ortopedi ve Travmatoloji Kliniği, İstanbul, Turkey.

Tel: +90 212 - 3735000 E-mail: mdmesutsonmez@yahoo.com 
In 1980, Dr. Kara designed an implant that enables elastic fixation, enabling a small degree of movement is accepted as a more physiological method. ${ }^{[13-15]}$ The aim of the present study was to investigate the radiological and functional outcomes in the long-term follow-up ( $\geq 10$ years) of patients who were treated with ANK nail for lateral malleolar fractures.

\section{MATERIALS AND METHODS}

The medical records of 163 patients with ankle fractures who had undergone surgical treatment with ANK nail in our clinic between January 1996 and January 1999 were retrospectively evaluated. Patients with multiple traumas, neuropathic arthropathy, and associated pilon fracture were excluded from the study. A total of 48 patients who underwent last evaluation were included in the study.

All patients were evaluated with respect to the etiology and type of fracture, time elapsed before surgery, and postoperative length of follow-up. The American Orthopedic Foot and Ankle Society (AOFAS) ankle/hind foot score was chosen as the primary outcome measure. Radiological assessment was done with weight bearing anteroposterior, lateral, and mortise views of the ankle obtained at the last followup. The grading system described by Morrey and Wiedemann was used to detect the presence of postoperative osteoarthritis. ${ }^{[16]}$

Statistical analysis of the data was performed using the Statistical Package for the Social Sciences software, version 13 (IBM Corp., Chicago, IL, USA).

\section{Characteristics of the ANK Nail}

The ANK nail (Hipokrat, Izmir, Turkey) is made from stainless steel and has a diameter of $2.5 \mathrm{~mm}$. It consists of a straight section that is applied intramedullary into the fibula. This is neither an expandable nor a press-fit implant. Therefore, the ANK nail is not suitable for long oblique and segmented distal fibular fractures. The implant has a curved distal section that is used to fix the fibula to the tibia and a screw hole at the distal tip of the curved section (Fig. Ia). Another piece that completes the instrument is the malleolar screw. The ANK nails for the right and left ankles are different.

\section{Surgical Technique}

The operations were performed under general or regional anesthesia, with the patient in supine position and a padding inserted under the ipsilateral hip. A $2.5-4 \mathrm{~cm}$ curved incision is made on the lateral aspect of the ankle under pneumatic tourniquet control, taking care not to injure the superficial peroneal nerve. The fibular fracture is exposed and reduced anatomically. The lateral cortex of the fibula is drilled with either a $2.2 \mathrm{~mm}$ drill or a $2.5 \mathrm{~mm}$ Kirschner wire, which are then advanced intramedullary and proximal to the fracture. Under fluoroscopic guidance, an ANK nail is inserted and advanced until its corner rests on the tip of the fibula. The widening of the syndesmosis is confirmed with the observation of the tibiofibular diastasis when the fibula is pulled laterally with a hook (Cotton test). The end of the ANK nail bearing the screw hole is placed on the tibia, and while keeping the foot in neutral flexion, the nail is fixed onto the anterior or anterolateral corner of the tibia with a malleolar screw. When the posterior malleolus is also fractured, the malleolar
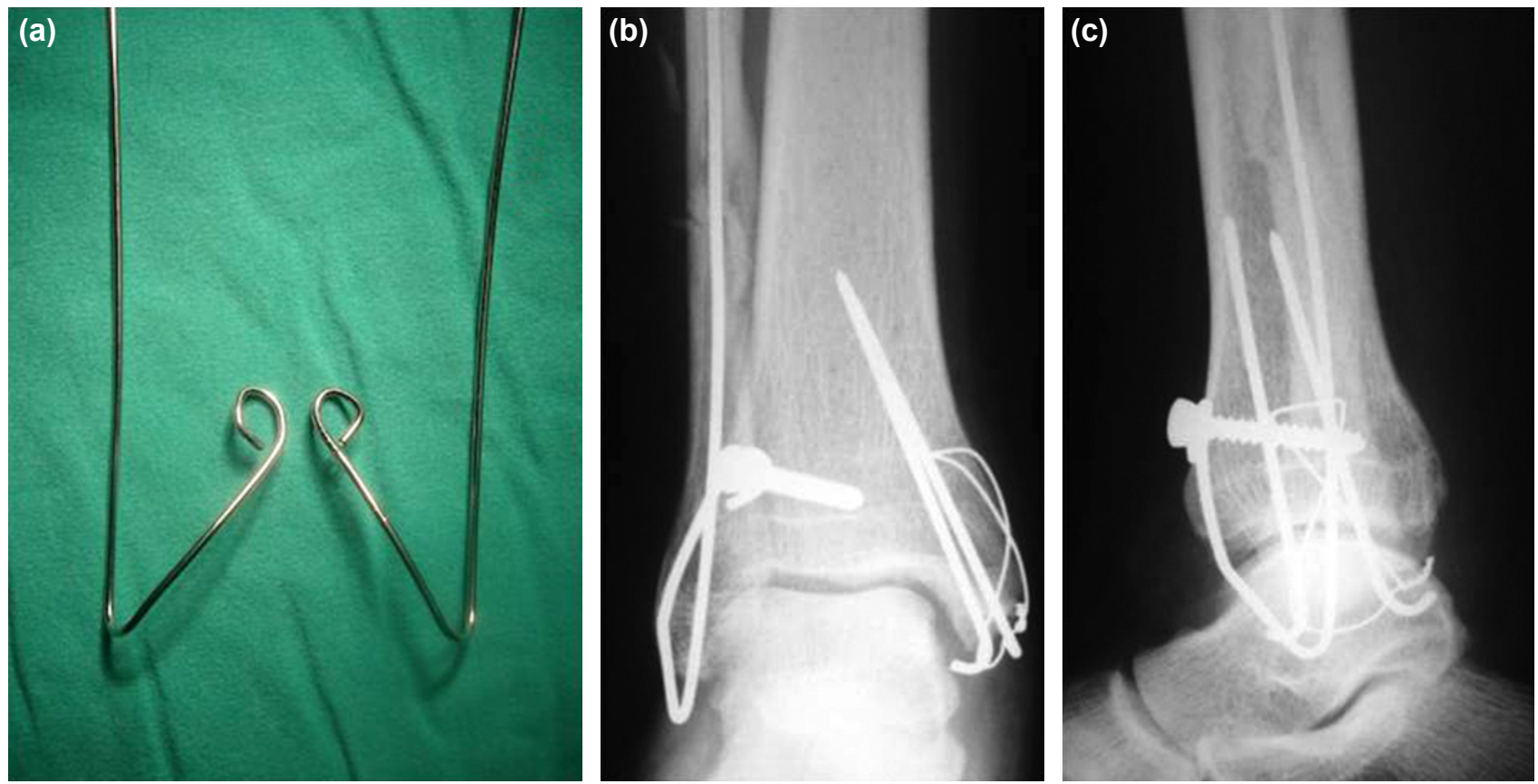

Figure 1. (a) ANK devices for the right and left ankles. A simple, $2.5 \mathrm{~mm}$ in diameter Kirschner wire that is curved distally is used. (b) Early postoperative anteroposterior X-ray. (c) Postoperative lateral view after ANK nail application. 
screw is inserted in a manner to include this fragment as well. The stability is reassessed using the traction test after fixation. A below knee cast splint, with the ankle at $90^{\circ}$, is applied after skin closure (Fig. Ib and c).

\section{Postoperative Care}

The operated extremity is elevated for a few days and kept in a cast splint for 2 weeks to decrease the pain. The splint is removed after 2 weeks, and full active range of motion exercises is initiated. Partial weight bearing is allowed after 6 weeks, and active flexion and extension movements are continued.

\section{RESULTS}

The study included 16 female and 32 male patients. The mean age of the patients was 37.3 (17-69) years. The mean length of postoperative follow-up was 129.9 (123-150) months. The cause of injury was a result of low-energy trauma (simple ankle sprain) in 24 patients and high-energy trauma (motor vehicle accident and fall from height). All fractures were classified according to the Denis-Weber classification, in which 22 patients were Weber type B, and 26 patients were Weber type C. Four patients had open fracture (Gustilo-Anderson type I in three patients and 2 in one patient). Of the patients, $26(54.16 \%)$ had bimalleolar fractures, 16 (33.33\%) had trimalleolar, and 6 (12.5\%) had isolated lateral malleolar fractures associated with syndesmosis injury.

There was a significant relationship between the presence of comorbidity (diabetes, hypertension, and vascular disease) and the development of posttraumatic arthritis, and arthritic changes were more common in these patients (Fisher's exact test, $\mathrm{p}=0.01 \mathrm{I}$ ).

There were no relationships between the AOFAS score, extension losses, and radiological osteoarthritis degrees $(p>0.05)$. There was a significant relationship between the loss of flexion and AOFAS score $(p=0.048)$.

Twenty-two patients had Weber type B fracture, and their mean AOFAS score was 93.36 points. The remaining 26 patients had Weber type $C$ fracture, and their mean AOFAS score was 97.66 points. There was no relationship between the type of fracture and the clinical outcome $(p>0.05)$. The mean grades of osteoarthritis were 0.68 in type $B$ fractures and 0.57 in type $C$ fractures. There was no significant relationship between the type of fracture and the development of osteoarthritis $(p>0.05)$.

Four patients had $>2 \mathrm{~mm}$ (mean $3.85 \mathrm{~mm}$ ) shortening of the fibula compared with the contralateral side, and their mean AOFAS score was 83.75 (80-90) points.

\section{DISCUSSION}

Distal tibiofibular syndesmosis injuries associated with an- kle fractures may result from low-energy trauma, including sports injuries, simple falls, or sprain, or high-energy trauma, including traffic accidents or falling from height.

A body weight of $80-90 \%$ is transferred to the talar dome through the tibial articular surface at the ankle during weight bearing. The remaining load is transferred through the fibular side by the syndesmosis ligaments and the lateral collateral ligaments. ${ }^{[17]}$ The fibula plays an important role in ankle stability, and the best outcomes in the management of its fractures can be achieved only with anatomic reduction to prevent the development of arthrosis. ${ }^{[18]}$

Transfixion of the fibula to the tibia is often necessary in tibiofibular syndesmosis injuries. It can be performed with a screw that holds three or four cortices, screw over a plate, button suture technique, or a bolt nail. ${ }^{[19,20]}$ Screw fixation is the most commonly preferred method. The distance of the screw to the ankle joint, whether ankle movement in the presence of the screw is allowed or not, and weight bearing in the presence of the screw are the major controversial aspects of this method. Micromotion and reactional loosening around the screw occurs in time. The possibility of breakage in an unremoved screw reaches $10-29 \%$ and is caused by the physiological longitudinal movement that occurs during loading. ${ }^{[2]]}$ ANK nail allows an elastic fixation in contrast to that of the rigid fixation of a screw. Therefore, the movements of the ankle and fibula are not restricted. In addition, it does not require removal due to its elasticity. Kabukcuoglu et al. ${ }^{[14]}$ reported excellent and good results, and early weight bearing was allowed.

The ANK nail makes an intramedullary fixation for the fractured fibula. The rotational stability in this method is provided by the screw applied to the tibia, as well as the contact of the implant with the fibular tip. The distal aspect of the ANK nail has a curvature that conforms to the fibular valgus. In addition to its contribution to rotational stability, this prevents any narrowing in the malleolar space. A distal crural computerized tomography (CT) assessment of all patients may be useful for the accurate assessment of residual rotation. We did not perform a CT scan in our study.

Fibular shortening has great significance with respect to the depth of the ankle mortise and, related to that, its balance. This significance is greater during weight bearing. ${ }^{[5]}$ The most important problem related to the ANK nail is the development of fibular shortness. Previous studies on the ANK nail performed in Turkey emphasized the possible development of fibular shortness due to intramedullary fixation. ${ }^{[13-15]}$ Kabukcuoglu et al. ${ }^{[14]}$ stated that they do not prefer the ANK nail in comminuted and long oblique fibula fractures and advocated that if the ANK nail will be used in such fractures, then cerclage wire support will be necessary. Comminuted fibula fractures were reported to result in collapse and shortness. In one of these previous studies, three fibular shorten- 
ing was reported among 42 patients operated with the ANK nail. ${ }^{[14]}$ In our study, four patients had a fibular shortening $>2$ $\mathrm{mm}$ (mean $3.85 \mathrm{~mm}$ ) compared with the contralateral side. In comparison to these patients with those without shortness, there was a significant difference with respect to the AOFAS scores and the development of osteoarthritis. The indications of ANK should be carefully determined, and the technique should be applied meticulously. In our study, we observed that the ANK nail was applied commonly in short oblique fractures. Reduction loss and fibular shortening appear inevitable when the ANK nail is used in long oblique fractures and segmented-comminuted metaphyseal fractures. Kara et al. ${ }^{[13]}$ reported that early weight bearing can lead to reduction loss in these types of fractures. The ANK nail appears to be inadequate for providing a rotational stability in the distal fibula. These two causes narrow the indications for the implant. ${ }^{[13-15]}$

Our study has several limitations. First, this is a retrospective study. Second, the results could have been more accurate with a randomized, prospective, controlled study. Finally, the results of fractures operated with the ANK nail were not compared with today's more popular methods, such as plate osteosynthesis.

Our study and others have shown that the ANK nail method does not yield very poor results in the management of ankle fractures associated with distal tibiofibular ligament injuries. ${ }^{[13-15]}$ Its main advantage is the lack of any need for implant removal. The cost is approximately equal to that of a single cortical screw. Fixation with the ANK nail is an appropriate method that can be applied in selected lateral malleolar fractures associated with syndesmosis injury.

\section{Ethical Standard}

All procedures were in accordance with the ethical standards of the responsible committee on human experimentation (institutional and national) and with the 1975 Declaration of Helsinki, as revised in 2008. Informed consent was obtained from all the patients included in the study.

Conflict of interest: None declared.

\section{REFERENCES}

1. Wuest TK. Injuries to the distal lower extremity syndesmosis. J Am Acad Orthop Surg 1997;5:172-81. [CrossRef]

2. Daly PJ, Fitzgerald RH Jr, Melton LJ, Ilstrup DM. Epidemiology of ankle fractures in Rochester, Minnesota. Acta Orthop Scand 1987;58:539-44.

3. Jensen SL, Andresen BK, Mencke S, Nielsen PT. Epidemiology of ankle fractures. A prospective population-based study of 212 cases in Aalborg,
Denmark. Acta Orthop Scand 1998;69:48-50. [CrossRef]

4. Yilmaz E, Karakurt L, Serin E, Bulut M. The results of surgical treatment in ankle fractures. Acta Orthop Traumatol Turc 2002;36:242-7.

5. Ovaska M. Complications in ankle fracture surgery. Acta Orthop Suppl 2015;86:1-32. [CrossRef]

6. Court-Brown CM, McBirnie J, Wilson G. Adult ankle fractures-an increasing problem? Acta Orthop Scand 1998;69:43-7. [CrossRef]

7. Regan DK, Gould S, Manoli A 3rd, Egol KA. Outcomes over a decade after surgery for unstable ankle fracture: functional recovery seen 1 year postoperatively does not decay with time. J Orthop Trauma 2016;30:236-41. [CrossRef]

8. van den Bekerom MP, Lamme B, Hogervorst M, Bolhuis HW. Which Ankle Fractures Require Syndesmotic Stabilization? J Foot Ankle Surg 2007;46:456-63. [CrossRef]

9. Lauge-Hansen N. Fractures of the ankle. II. Combined experimentalsurgical and experimental-roentgenologic investigations. Arch Surg 1950;60:957-85. [CrossRef]

10. Weening B, Bhandari M. Predictors of functional outcome following transsyndesmotic screw fixation of ankle fractures. J Ortho Trauma 2005;19:102-8. [CrossRef]

11. Manjoo A, Sanders DW, Tieszer C, MacLeod MD. Functional and radiographic results of patients with syndesmotic screw fixation: implications for screw removal. J Orthop Trauma 2010;24:2-6. [CrossRef]

12. van Dijk CN, Longo UG, Loppini M, Florio P, Maltese L, Ciuffreda M, et al. Conservative and surgical management of acute isolated syndesmotic injuries: ESSKA-AFAS consensus and guidelines Knee Surg Sports Traumatol Arthrosc 2016;24:1217-27. [CrossRef]

13. Kara AN, Esenyel CZ, Sener BT, Merih E. A different approach to the treatment of the lateral malleolar fractures with syndesmosis injury: the ANK nail. J Foot Ankle Surg 1999;38:394-402. [CrossRef]

14. Kabukcuoglu Y, Kucukkaya M, Eren T, Gorgec M, Kuzgun U. The ANK device: a new approach in the treatment of the fractures of the lateral malleolus associated with the rupture of the syndesmosis. Foot Ankle Int 2000;21:753-8. [CrossRef]

15. Xie B, Jing Y, Xiang L, Zhou D, Tian J. A modified technique for fixation of chronic instability of the distal tibiofibular syndesmosis using a wire and button. J Foot Ankle Surg 2014;53:813-6. [CrossRef]

16. Morrey BF, Wiedeman GP Jr. Complications and long-term results of ankle arthrodeses following trauma. J Bone Joint Surg Am 1980;62:77784. [CrossRef]

17. Kapandji IA. The physiology of the joints. 6 th ed. New York: Churchill Livingstone; 2007. p.1-2.

18. Yablon IG, Segal D, Leach RE. Ankle injuries. New York: Churchill Livingstone; 1983. p. 268.

19. Campbell WC, Canale ST, Beaty JH. Campbell's operative orthopaedics. 11th ed. Philadelphia: Mosby/Elsevier; 2008.

20. Cottom JM, Hyer CF, Philbin TM, Berlet GC. Transosseous fixation of the distal tibiofibular syndesmosis: comparison of an interosseous suture and endobutton to traditional screw fixation in 50 cases. J Foot Ankle Surg 2009;48:620-30. [CrossRef]

21. Bell DP, Wong MK. Syndesmotic screw fixation in Weber C ankle injuries--should the screw be removed before weight bearing? Injury 2006;37:891-8. [CrossRef] 


\section{ORİIINAL ÇALIŞMA - ÖZET}

Synesmoz yaralanmasının eşlik ettiği lateral malleol kırıklarının ANK çivisi ile tedavisi: On yıllık tedavi sonuçları

\section{Dr. Sinan Kahraman, ${ }^{1}$ Dr. Hasan Hüseyin Ceylan, ${ }^{2}$ Dr. Mehmet Mesut Sönmez, ${ }^{3}$ Dr. Ayhan Nedim Kara ${ }^{1}$}

${ }^{1}$ İstanbul Bilim Üniversitesi Tıp Fakültesi, Ortopedi ve Travmatoloji Kliniği, İstanbul

${ }^{2}$ İstanbul Lütfiye Nuri Burat Devlet Hastanesi, Ortopedi ve Travmatoloji Kliniği, İstanbul

${ }^{3}$ Hamidiye Şişli Etfal Eğitim ve Araştırma Hastanesi, Ortopedi ve Travmatoloji Kliniği, İstanbul

AMAÇ: Syndesmoz yaralanmasının eşlik ettiği lateral malleol kırıkları oldukça sıktır. Syndesmoz yaralanmaları için birçok çeşit implant kullanılmaktadır. Bunlardan birisi de ANK çivisidir. Çalışmamızın amacı syndesmoz yaralanmasının eşli ettiği ayak bileği kırıklarında ANK çivisi ile tedavinin uzun dönem klinik ve radyolojik sonuçlarını değerlendirmektir.

GEREÇ VE YÖNTEM: En az 10 yıllık takibi yapılabilen 48 hastanın son kontrollerinde AOFAS (American Orthopaedic and Foot Society) klinik değerlendirme formu kullanılarak klinik sonuçları ve radyolojik değerlendirme kriterleri ile artroz varlığı araştıııldı.

BULGULAR: Hastaların ortalama yaşı 37.3 idi ( I7-69). Hastalar ortalama I 29.9 ay (I23-150) takip edildi. Weber B kırığa sahip 22 hastada ortalama AOFAS skoru 93.36 idi. Weber C kırığa sahip 22 hastada ortalama AOFAS skoru 97.66 idi. Kırık tipi ile AOFAS skoru arasında istatiksel olarak anlamlı fark saptanmadı. Travma sonrası artroz gelişimi ile fibula kısalı̆ı arasında anlamlı fark saptandı.

TARTIŞMA: ANK çivisi özellikle seçilmiş olgularda; syndesmoz yaralanmasının eşlik ettiği ayak bileği kırıklarında başarılı şekilde uygulanabilir. Özellikle maliyet açısından oldukça avantaja sahiptir.

Anahtar sözcükler: ANK çivisi; ayak bileği kırıkları; syndesmoz yaralanması.

Ulus Travma Acil Cerrahi Derg 2019;25(1):75-79 doi: 10.5505/tites.2018.91679 